\title{
DICO ERGO SUM
}

\section{С.В. Куцепал}

У царині філософської рефлексії можна виділити два рівні дослідження: перший складають так звані «вічні теми» (Абсолют, субстанція, свідомість тощо), другий - ті, що виникають у площині «вічних тем», конкретизуючи та деталізуючи останні. Яскравим прикладом проблеми, що поступово перебирає на себе певні ознаки «вічної теми», $\epsilon$ феномен мови з усією палітрою можливих барв і відтінків - від споконвічної проблеми тлумачення та розуміння до нових несподіваних міксів на кшталт «семантика політики», «семіологія моди», «мова віртуальної реальності» тощо.

Палітра дослідження мови у філософських школах і напрямках надзвичайно яскрава та різнобарвна: онтологія мови (В. фон Гумбольдт, М. Бубер, М. Бахтін, М. Хайдеггер та ін.); філософія імені (П. Флоренський, С.Булгаков, О. Лосєв); логічний аналіз мови (Г. Фреге, Р. Карнап, Б. Рассел); прагматика мови (Д. Дьюї, У. Куайн, П. Строссон); герменевтика (Г.-Г. Гадамер); комунікативна філософія (Ю. Хабермас, К.-О. Апель); структурний психоаналіз (Ж. Лакан); граматологія (Ж. Дерріда); онтологія дискурсу (Р. Барт, Ю. Крістєва) тощо.

Своєрідною революцією у трактуванні мовної проблематики стає лінгвістична концепція $\Phi$. де Соссюра, яка видається результатом епістемологічного розриву, здійсненого обгрунтуванням структурної лінгвістики в історії мовознавства. Учений зосереджує увагу на синхронічному, коекзистенційному, систематичному характері єдності слів i звуків. Його розмежування загального феномена мови на «langue» та «parole» заснована на топологічному поділі на дві фундаментальні площини мови - за індивідуально здійсненим мовленням, щоденними мовними актами індивідів з мовною компетенцією знаходиться стру-

Актуальні проблеми духовності

(Відп. ред.: Я.В. Шрамко)

Кривий Ріг (2007), 62-71 
ктурована єдність мовних елементів, які існують в силу своєї опозиції і відмінності щодо всіх інших елементів як моментів системної структури. Завдяки такому підходові структурна лінгвістика почала відмежовуватися від безпосередності індивідуального мовного озвучення, здійснилася редукція множинності площин індивідуального мовлення до системи опозитивних і розрізнених мовних конституентів, які це мовлення засновують та уможливлюють. Наслідком такого розуміння мови стає концепція довільності знака, сформульована Ф. де Соссюром, за якою знак являє собою єдність позначуваного та позначуючого, при цьому позначуюче $є$ невмотивованим, тобто довільним відносно даного позначуваного, з яким у нього в дійсності немає жодного природного зв'язку.

Епохальну роль у справі подолання відстані між мовою та дійсністю відіграв «Логіко-філософський трактат» Л.Вітгенштейна, у передмові до якого філософ писав: «Те, що може бути висловленим, може бути висловленим ясно, про що ж не може йти мова, про це потрібно мовчати» $[2$, с.3]. На думку вченого, кожному реченню відповідає певний можливий факт, якщо він має місце, речення істинне, у іншому випадку - хибне, а наведення всіх істинних елементарних речень повністю описує світ. «Між елементарними реченнями та фактами існує відношення ізоморфізму, складені речення $є$ функції істинності елементарних речень» [2, с. 35]. Ізоморфізм між мовою та світом виникає завдяки тому, що мова поділяє зі світом свою логічну форму і завдяки останній відноситься до світу. Образ і дійсність поєднуються через форму відображення, а логічний образ і дійсність пов'язуються через логічну форму відображення, яка $є$ загальною основою мови та світу, оскільки саме завдяки їй речення отримує смисл (= може бути істинним або хибним). Л. Вітгенштейн робить висновок, що речення, яке не відповідає логічній формі, - беззмістовне, прикладами таких речень $є$ більшість положень традиційної філософії.

У рамках репрезентованої теми доречно звернутися до концепції структурного психоаналізу Ж.Лакана, вихідною тезою якої виступає твердження про те, що несвідоме структуроване як мова. Відштовхуючись від такої методологічної настанови, вчений намагається Знайти засоби раціонального тлумачення несвідомого, встановити взаємозв'язок і взаємозалежність емпіричного та теоретичного рівнів несвідомого, сформулювати некласичні принципи дослідження буття та пізнання. Для Ж. Лакана стає очевидним, що суб'єкт не може вичерпуватися картезіанським cogito, оскільки суб'єкти буття та мислення існують на різних рівнях. Наслідком цього усвідомлення стає нове розуміння ролі 
мови як опосередковуючої ланки між буттям та мисленням, що призводить до перегляду класичного постулату cogito ergo sum, оскільки традиційна двочленна формула зв'язку буття та свідомості виявляється хибною. Мова наділяється творчою функцією, котра тлумачиться як функція символічного, первинного відносно буття та свідомості, а мова оголошується універсальним джерелом креативності, яке породжує поняття і речі, адже коли ми мислимо, відбувається заміна живого або неживого предмета словом, таким чином поняття заміщують речі.

Ще одним важливим моментом лаканівської концепції сутності несвідомого є теза про те, що несвідоме-це чистий час речі, а його матеріальною передумовою може бути будь-що, тому будь-який учинок - це мова. Стверджуючи вищенаведене, Ж. Лакан спростовує гегелівський постулат про поняття як час речі і одночасно полемізує 3 фрейдівською настановою, згідно з якою несвідоме знаходиться поза часом.

Ж.Лакан будує свою концепцію шляхом «десексуалізації» фрейдизму та «десеміотизації» лінгвістичної концепції Ф. де Соссюра. Мислитель вибудовує власну версію, відповідно до якої несвідоме бажання потрактовується як структурно впорядкована пульсація. Внаслідок пульсації несвідоме втрачає хаотичність, стає окультуреним, завдяки чому пульсації трансформуються у твори мистецтва та явища культури. Внутрішній структуруючий механізм об'єднує всі рівні психіки, функціонує за аналогією з мовою, тобто встановлюється своєрідна мова пульсацій на рівні уявного, де ще немає розмежування психології та фізіології. Саме тому для вирішення проблем несвідомого Ж. Лакан використовує лінгвістичні аналогії, стверджуючи тезу про те, що несвідоме структуроване як мова, оскільки саме вона уводить суб'єктивність людини у світ культури, у сферу універсального. «Суб'єкт змушений виокремлювати, виділяти із дискурсу все, що має відношення до заборонених законом тем. Тому заборона ця залишається як така абсолютно незрозумілою. На рівні реальності ніхто не здатен зрозуміти, чому за те, що він висловить цю правду, йому відрубають голову: ніхто не розуміє навіть, де сам факт заборони має місце. I тоді не варто вже розраховувати на те, що будь-хто, хто висловить то, що промовляти заборонено, і повірить, нібито все дозволено, зможе тим самим просто скасувати закон як такий» [3, с.186].

Несвідоме стає впорядкованим та окультуреним лише завдяки тому, що воно структуроване в мові, відтак несвідоме для Ж. Лакана це «мова Іншого»: «Саме світ слів і породжує світ речей, спочатку 
змішаних у цілому „тут і зараз“, що перебуває у процесі становлення; породжує, повідомляючи їх сутності своє конкретне буття, а тому, що $\epsilon$ одвічним - свою всезагальність» $[4$, с. 46$]$.

Філософ змінює акценти при розгляді зв'язку між означуваним та означуючим i, на відміну від $\Phi$.де Соссюра, доводить, що вони не являють собою два боки одного аркуша паперу, а, навпаки, мають здатність вислизати один від одного, проявляти самостійність. Спостерігаючи за хворими, Ж. Лакан (як практикуючий лікар) прийшов до висновку, що у мовному потоці пацієнта-невротика означуюче відривається від означуваного, а останнє саме і необхідно виділити у процесі діалогу, розплутати мовні вузли, знявши тим самим хворобливе напруження, тобто між означуваним та означуючим не відбувається поєднання. Наслідком такого вислизання стає те, що з мовного потоку хворого можуть випадати цілі блоки означуваного, тому структурний психоаналіз покликаний досліджувати структуру мовного потоку на рівні означуючого, яка співпадає зі структурою несвідомого. Для Ж.Лакана саме мова являє собою сферу здійснення «несистематизації», «невибірковості» одних психічних проявів відносно інших, вона постає тим нейтральним грунтом, де зберігаються сліди та позначки психічних станів і процесів різного рівня. Завдяки мові уможливлюється логічний аналіз психічних процесів, бо лікар має змогу структурувати та впорядковувати мову хворого.

На відміну від фрейдівського психоаналізу, де владарює монолог хворого, у лаканівський схемі головна роль належить діалогу, оскільки завдання лікаря полягає в тому, щоб допомогти хворому створити власну історію на матеріалі тих розрізнених та підсвідомих фрагментів, котрі виявляються під час сеансу. «Несвідоме виступає главою моєї власної історії, але ця глава обов'язково повинна пройти цензуру, оскільки має певні лакуни, а в деяких місцях навіть позначена брехнею. Але істина обов'язково має бути віднайдена, навіть тоді, коли вона записана у зовсім іншому місці» [11, с. 259].

Несвідоме міститься в неусвідомлюваних особливостях мови хворого-синтаксичних, лексичних, семіотичних. Для того, щоб з'ясувати приховану істину, розкрити зміст інтенцій пацієнта, лікар має відігравати роль співшукача цієї істини, а не носія такої собі зовнішньої істини по відношенню до нього, що прикметно для психоаналізу. Сама присутність психіатра є інстанцією звернення, оскільки необхідною умовою лаканівського методу є наявність того, хто уважно слухає. Для Ж. Лакана існує два різновиди мови хворого: «порожня» - $з$ якою пацієнт звертається до лікаря на початку сеансу, вона не містить у собі 
матеріалу аналізу; значно важливіша «повна» (pleine) мова, котра характеризується наявністю смислових згустків або, навпаки, розривів. Саме в них і концентруються симптоми хвороби, а розшифрування таких вузлів $є$ завданням аналітика.

Отже, минуле століття було позначене тим, що мова та її складники отримали статус «універсальної форми», здатної не лише до перетворювальної, а й до творчої діяльності, наслідком чого стає створення нових соціальних та культурних реалій. Більш того, мова (разом зі свідомістю) постає єднальною ланкою роз'єднаних пізнавальних дискурсів (наука, політика, мистецтво, етика тощо).

Причин такого стану речей можна назвати кілька.

По-перше, пригадаємо твердження М. Хайдеггера «буття потребує людини для того, щоб здійснитися самим собою серед існуючого і зберегтися у якості буття» [8, с. 254]; перефразовуючи його думку, зауважимо, що людина потребує комунікації (мови) задля здійснення самої себе та збереження самобуття.

По-друге, дослідник сучасного мовного простору (у тому числі і тексту) має поставити себе «всередину» комунікаційного акту ${ }^{1}$, оскільки це надасть йому змогу побачити свою позицію ззовні, визначити власний шлях у лабіринті рівно можливих ризоматичних шляхів, уможливлює спостереження за розгортанням та функціонуванням знакової реальності ${ }^{2}$. Результатом стає перехід з теоретичного рівня дослідження та опису феномену комунікації на мета-теоретичний, завдяки чому мова позбавляється статусу апріорі, отримує трансцендуючий характер і приписує семіотичний статус усім іншим утворенням реальності. Наслідком такого уподібнення свідомості тексту стає інтертекстуальне розчинення суверенної суб'єктивності людини у текстах, які складають так званий «великий інтертекст культурної традиції» (І. Ільїн).

По-третє, мова отримує онтологічний статус, саме вона перетворює можливі варіанти розвитку та існування об'єктивної реальності на подіï, розриваючи універсальну тканину буття, виступає Іншим відносно свідомості, передбачає реальність неможливого як можливого; «мова - онтологічний досвід світу» (Г.-Г. Гадамер)

\footnotetext{
13нову пригадуються слова М. Хайдеггера: «... в оселі мови живе людина» [8, c. 192$]$

2 У зв'язку з цим звернемося до праці П. Флоренського «Думка та мова», де мислитель, розмірковуючи над проблемою символічності слова, стверджує, що остання для свого розв'язання «потребує вживання в те, що іменується, медитації над ним, ... містичного осягнення його» $[7$, с. 212].
} 
По-четверте, однією з вузлових тем сучасного філософування стає визначення відношення між мовою, історією та суб'єктом, методологічним інструментом для чого $є$ поняття «дискурс».

По-п'яте, представники класичної німецької філософії та феноменології переконливо довели, що людське буття являє собою єдність ідеальних градацій, які застосовуються свідомістю до реальності, і властивостей останньої. Завдяки мові людська діяльність містить у собі ідеальні та абсолютні виміри, що продукуються свідомістю. Це також підтверджує необхідність визнання онтологічного статусу мови, яка постає формою репрезентації буття як тотального континууму.

Отже, щоб зрозуміти мову, необхідні дві умови: 1) перебувати у мові; 2) працювати 3 мовою. Дотримання цих умов визначає категоріальний каркас філософського тлумачення мови, найбільш наочно представлений у філософії французького постмодернізму: «висловлювання - текст - дискурс - інтертекст».

При цьому під висловлюванням розуміється будь-яке твердження про дійсність (як істинне, так і хибне), текст являє собою або сукупність висловлювань (монолог), або послідовність фраз між двома полюсами комунікації (діалог), пов'язаних між собою єдиним смислом. Тобто, атрибутами тексту є 1) наявність інституційних рамок, завдяки чому суттєво обмежуються акти висловлювання; 2) наявність історичної, соціальної та інтелектуальної спрямованості. Таке розуміння тексту дозволяє використати до нього метод структурного аналізу.

Нагадаємо, що у класичному варіанті структурний метод передбачає використання таких процедур: 1) виділення первинної множини об'єктів, у яких можна припустити існування єдиної структури; 2) розчленування об'єктів (текстів) на окремі частини, де типовими $\epsilon$ такі, що постійно повторюються, а відношення пов'язують різнорідні пари елементів; 3) систематизація останніх і побудова абстрактної структури або шляхом безпосереднього синтезування, або формальнологічного чи математичного моделювання; 4) виведення із структури всіх теоретично можливих наслідків та їх практична перевірка.

Р.Барт переосмислює класичний метод структурного аналізу на основі принципового розмежування денотації та конотації. Під денотативним значенням слова розуміється не сам предмет (конкретна одиничність), а типові уявлення про нього, клас об'єктів, що володіють зазначеними номінативними властивостями. Конотативним значенням слова вважається будь-яка додаткова відносно денотативної смислова інформація. Денотативні значення завжди подаються у явній формі, експліцитно, а конотативні - імпліцитно, закодовано. 
Р.Барт прагне у будь-якому тексті віднайти денотативне («буквальне») повідомлення, яке зводиться винятково до свого предметного значення і $є$ вільним від будь-яких конотативних смислів, та конотативне (символічне), що приймає форму або асоціацій, або реляцій, коли встановлюється певне відношення між двома частинами тексту, що на перший погляд зовсім не пов'язані між собою. «Наші лексії повинні стати ніби чарунками решета, якомога меншими чарунками, за допомогою яких ми будемо „знімати пінку“ сенсу, відшукуючи конотації» $[1$, c. 427$]$.

Сутність методу текстового аналізу полягає у заміні поняття «структура» поняттям «структурація», тобто у відмові від тлумачення твору як певного цілого, котре характеризується стійкою незмінною структурою, та акцентуванні на рухливості і мінливості тексту як процесу «структурації». Як стверджує Р. Барт, текстовий аналіз не ставить за мету опис структури твору, завдання вбачається не в тому, щоб зареєструвати певну сталу структуру, а в тому, щоб провести рухому, змінну протягом Історії структурацію тексту, проникнути у смисловий обсяг твору, у процес позначування, побачити, як текст вибухає та розсіюється у міжтекстовому просторі. За допомогою текстового аналізу дослідник прагне віднайти та класифікувати не всі смислу тексту (це неможливо тому, що текст відкритий у нескінченність), а лише ті форми та коди, через які відбувається виникнення смислів тексту, тобто простежити шляхи смислоутворення.

Р.Барт уводить п'ять кодів, причому саме поняття код розуміється у суто структуралістському сенсі як зібрання правил чи обмежень, які забезпечують комунікативне функціонування будь-якої знакової системи (у цьому разі - мови). Отже, це - культурний, герменевтичний, символічний, семічний і проайретичний (наративний) коди, призначені для пояснення конотацій лексій.

Пізніше Р.Барт дещо переробив систему кодів у праці «Текстовий аналіз однієї новели Едгара По»; відтак остаточно вона має такий вигляд:

1. Культурний код, складниками якого постають науковий, риторичний, хронологічний, соціо-історичний коди, сутністю зазначеного коду є знання як корпус правил, вироблених суспільством.

2. Код комунікації («адресації), особливість якого полягає у тому, що він апріорі не осягає всіх можливих варіантів означування, які розгортаються у тексті, а лише вказує на ті відношення, котрим текст надає форму звернення до адресата. 
3. Символічний код надає змогу структурування твору.

4. Код дії (атракційний) підтримує фабульний каркас твору: дії або висловлювання, які їх денотують, організуються у ланцюжки.

5. Код таємниці, загадки (енігматичний, герменевтичний), завдяки якому основне питання увінчується відповіддю.

Взаємопов'язаним з текстом є поняття «дискурс»-це вже та картина дійсності, яка є результатом усвідомлення тексту, тобто класифікація об'єктів дійсності на основі семантичних зв'язків між ними, «теоретичний об'єкт, що спонукає до розмислів про відношення між мовою та ідеологією» [5, с. 554]. На думку П. Серіо, «дискурс-це висловлювання, яке розглядається з точки зору дискурсивного механізму, котрий ним керує. Таким чином, погляд на текст з позиції його структурування ,.у мові“ визначає даний текст як висловлювання; лінгвістичне дослідження умов створення тексту визначає останній як ,дискурс“» $[5, \text { с. } 550]^{3}$.

Царина дискурсу продукує термін «інтертекст» (intertextualité), який утверджується серед філософського загалу у другий половині 60-х років минулого століття. Його найбільшими популяризаторами стають Юлія Крістєва та Ролан Барт. Як і інші представники філософіï постмодернізму, ці мислителі прагнули подолати методологічний монізм та замінити його поліметодологічним підходом, визначити ступінь самодостатності феноменологічного методу вивчення свідомості, мови, світу. Згідно з Р. Бартом, «будь-який текст є інтертекстом; інші тексти присутні у ньому на різних рівнях у формах, які можна розпізнати більшою чи меншою мірою: це тексти попередньої культури та тексти існуючої культури. Кожен текст - нова тканина, виткана зі старих цитат. Залишки культурних кодів, формул, ритмічних структур, фрагменти соціальних ідеом тощо - всі вони ввібрані текстом і перемішані у ньому, оскільки завжди до тексту і навколо нього існує мова. Як необхідна передуюча умова для будь-якого тексту, інтертекстуальність не може бути зведена до проблеми джерел та впливів; вона являє собою загальне тло анонімних формул, походження яких рідко

\footnotetext{
${ }^{3}$ Аналізуючи можливість визначення поняття «дискурс», корисно також пригадати розвідку М. Пешьйо (Pêcheux) «Автоматичний аналіз дискурсу», де автор своєрідно інтерпретує ідею Ф.де Соссюра про розмежування мови та мовлення. М. Пешьйо репрезентує дискурс як нове розуміння мовлення, позбавлене суб'єктивних імплікацій.
} 
можна виявити, безсвідомих або автоматичних цитат, що подаються без посилань» [9, с. 78].

Запропоноване Ю. Крістєвою тлумачення інтертексту відрізняється від бартівського. По-перше, інтертекст вона розуміє не як зібрання цитат із творів різних авторів, бо у такому разі це був би банальний продукт творчості ножиць і клею, а як простір зустрічі різноманітних цитацій. При цьому цитата виступає лише частковим випадком цитації, предметом якої є не окремі фрази, абзаци чи уривки, запозичені з інших творів, а всі можливі дискурси, з яких складається культура і в атмосферу яких занурюється будь-який автор незалежно від власної волі та бажання. Тому будь-який текст за своєю природою $€$ інтертекстом, а літературне слово постає місцем перетину текстових площин. По-друге, процедуру виникнення інтертексту Ю. Крістєва називає «читанням-письмом»: «інтертекст пишеться у процесі зчитування чужих дискурсів і тому будь-яке слово (текст) є таким перетином інших слів (текстів), де можна прочитати щонайменше ще одне слово (текст)» $[10$, с. 145]. По-третє, концепція інтертексту Ю. Крістєвої має динамічний аспект, інтертекстова структура не наявна, але виробляється відносно іншої структури. Саме в інтертексті попередні тексти зустрічаються та взаємодіють один з одним, причому виникнення нової структури передбачає активне відношення прийняття-неприйняття до всього попереднього текстового матеріалу, «будь-яка попередня структура або спирається на іншу структуру, або їй протистоїть» $[10$, c. 144].

Завдяки поняттю «інтертекст» у філософському просторі постсучасності утверджується теза про можливість «прочитання» будь-якого феномена (влада, історія, суспільство, політика, мода тощо). Уся людська реальність взагалі, а культура зокрема, трактується як інтертекст, який, своєю чергою, не є сталим і незмінним, а створює собою перед-текст будь-якого тексту, можливого у майбутньому.

Декілька століть тому Декартова теза «Cogito, ergo sum» змінила уявлення філософії про сутність людини та пізнання, підняла на знамено розуміння і утвердження людини через думку; заклала первні нової філософії. Філософія ХХ століття сформулювала нову тезу «Loquer, ergo sum», визначивши засадничим атрибутом людини здатність висловлювати свої думки, а не лише їх продукувати.

Р.Рорті, оцінюючи нову філософську реальність кінця минулого століття, стверджував: «Картина античної й середньовічної філософiї, що займалась речами, картина філософії з XVII по XIX ст., що займалась ідеями, і картина сучасної філософії, що займається слова- 
ми, цілком правдоподібна» [6, с. 194].

Сучасна філософія спрямована на всебічне дослідження людської особистості, розкриття її творчого потенціалу, пошук шляхів самовдосконалення та акцентування уваги на сутнісному самоздійсненні. Саме ця проблематика єднає різні напрямки та стилі філософування у прагненні осягнути сенс і дійсність буття, визначити його гносеологічні і аксіологічні зрізи, створити антропологізовану онтологію.

Цілісне розуміння людини неможливе без звернення до феномена мови у її дійсності та дієвості; мови, що виражає інтенції людини у буттєвій тотальності, надає можливість теоретико-філософського осягнення однієї з найбільших таємниць Універсуму - присутності Людини у світі.

\section{1 Бібліографія}

[1] Барт Р. Избранные работы: Семиотика: Поэтика. - М., 1989.

[2] Витгенштейн Л. Логико-философский трактат // Витгенштейн Л. Философские работы. Ч.1.- М., 1994.

[3] Лакан ЖК. Семинары. Книга 2: «Я» в теории Фрейда и в технике психоанализа. - М., 1999.

[4] Лакан Ж. Функция речи и поле языка в психоанализе. - М., 1995.

[5] Серио П. Анализ дискурса во французской школе (дискурс и интердискурс) // Семиотика: Антология. - М., 2001.-C.549-563.

[6] Рорти Р. Философия и зеркало природы. - Новосибирск, 1997.

[7] Флоренский П.А. Мысль и язык // Флоренский П. У водоразделов мысли. - М., 1990.

[8] Хайдеггер М. Время и бытие.-М., 1993.

[9] Barthes R. Texte // Encyclopedia universalis. Vol. 15. - P., 1973.

[10] Kristeva J. Semiotiké. Recherches pour une sé manalyse.-P., 1969.

[11] Lacan J. Écrits. - P., 1966. 